\title{
Effect of Working Capital, Asset Turnover and Sales Growth Limited Return on Assets on Food and Beverage Industry
}

\author{
Jumeida Simatupang1 ${ }^{1}$, Eka Purnama Sari ${ }^{1}$
}

\begin{abstract}
This study uses financial management theory related to variable Return On Assets, Working Capital, Asset Turnover and Sales Growth. The approach used is an associative approach. The population in this study is food and beverage companies listed on the Indonesia Stock Exchange IDX period 2017-2019. Samples were taken using multiple linear regression analysis methods, classic assumption test, $t$ test (partial test), f test (simultaneous test) and SPSS 24.0 software assistance determination coefficient (Statistical Product and Service Solution). So obtained 12 companies as samples. The results showed that: Working Capital has no significant effect on Return On Asset, Asset Turnover has no significant effect on Return On Asset, while Sales Growth also has no significant effect on Return On Asset. And simultaneously Working Capital, Turnover Assets and Sales Growth has no effect and is insignificant to Return On Asset.
\end{abstract}

Keywords: Working Capital, Asset Turnover, Sales Growth, Return on Assets

DOI : https://doi.org/10.30596/ijbe.v2i2.6655

JEL Classification: G, D24, F43

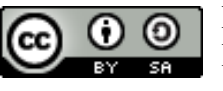

Published by International Journal of Business Economics (IJBE), Indonesia | Copyright $\odot 2021$ by the Author(s) | This is an open access article distributed under the Creative Commons Attribution License http://creativecommons.org/licenses/by/4.0), which permitsunrestricted use, distribution, and reproduction in any medium, provided the original work is properly cited.

Cite this article as:

Simatupang, J., \& Sari, E. P. (2020 Effect of Working Capital, Asset Turnover and Sales Growth Limited Return on Assets on Food and Beverage Industry. International Journal of Business Economics (IJBE), 2(2), 143-154.

Universitas Potensi Utama

Jl. KL Yos Sudarso Km 6,5 No 3A, Tanjung Mulia,

Medan Deli, Medan City, North Sumatra 20241, Indonesia

*Corresponding Author: mey05simatupang@gmail.com 


\section{International Journal of Business Economics (IJBE)}

Vol, 2 Issue 2, pp 143-154, March - August 2021

http://jurnal.umsu.ac.id/index.php/ijbe

eISSN 2686-472X

\section{INTRODUCTION}

In modern times today there is a growing number of companies established to achieve the goal of improving a company to achieve prosperity for the shareholders of a company. Financial report is an indispensable media tool for a company that is used for the most important communication tools to connect the parties of the company and activities carried out by the company related to the efforts to obtain the necessary funds at the lowest possible cost for the company.

In general, the purpose of a company established is to generate profit for its owners (Rudianto, 2006). The profit generated by the company is closely related to the level of profitability of the company itself. The Profitability Ratio describes the company's ability to make a profit through all existing capabilities and resources such as sales activities, cash, capital, number of employees, number of branches, and so on (Harahap, $2011 \mathrm{p}$. 304). High profitability shows that the company is more effective in carrying out its operations so as to increase optimal profit. On the contrary, low profitability illustrates that the company is less efficient in carrying out its operations so that it is less able to generate optimal profit

Return on Asset (ROA) is a tool for measuring a company's financial performance, ROA is a profitability ratio that measures a company's ability to generate profits from the use of all its resources or assets. According to (Munawir, 2014 p. 33), Return On Asset (ROA) is a form of profitability ratio which is intended to be able to measure the company's ability with the overall funds invested in activities used for company operations to generate profits.

Thus, this ratio connects the profits obtained from the company's operations (Net Operating Income) with the amount of investment or assets used to generate operating profits (Net Operating Assets). With this, the higher the Retrun On Asset (ROA), the performance of a company is more effective. This will increase the attractiveness of a company to investors.

Working Capital is the excess of current assets against short-term debt. This advantage comes from long-term debt and equity, which is known as net working capital (Ambarwati et al., 2015). Therefore the company needs a source of financing or funds with an increase in sales. So that with an increase in sales, the company's profitability will also increase (Supriadi \& Puspitasari, 2012). Working Capital management is very important in the company, because it includes making decisions about the amount and composition of current assets and how to finance these assets. Companies that cannot take into account a satisfactory level of working capital, then the company may experience insolvency (unable to meet matured obligations) and may even have to be liquidated. Current assets must be large enough to cover current debts in such a way that reflects a satisfactory level of safety (margin safety). Meanwhile, if the company determines the excess working capital, it will cause the company to be over liquid, which will result in idle funds

Asset turnover is including the comparison of sales with the total assets of a company which explains the turnover speed of total assets in a certain period in a financial report. Fixed assets turnover is the position of fixed assets and the estimated turnover time of fixed assets can be assessed by calculating the turnover rate of fixed assets by dividing sales by total net fixed assets. It can be concluded that fixed assets turnover is determined by two main factors, namely sales and total net fixed assets. What is meant by total net assets is total fixed assets after deducting depreciation of fixed assets (Andari et al., 2016) 


\section{International Journal of Business Economics (IJBE)}

Vol, 2 Issue 2, pp 143-154, March - August 2021

http://jurnal.umsu.ac.id/index.php/ijbe

eISSN 2686-472X

Sales Growth is an important indicator of market acceptance of a company's products / services, where the revenue generated from sales can be used to measure the rate of sales growth. The proxy used in this research is sales growth, which is the difference between the amount of sales in this period and the previous period compared to the sales of the previous period (Hotimah \& Joni, 2014).

The higher the growth of the company, the more the company will rely on capital. High sales growth indicates an increase in the revenue the company gets from selling products in the company's operational activities. Sales growth from the previous year can be used periodically to predict sales growth in the coming year (Meidiyustiani, 2016).

Return On Assets (ROA) is a form of profitability ratio which is intended to measure the company's ability with the overall funds invested in the activities used for the company's operations to generate profits. Thus this ratio connects the profits obtained from the company's operations (Net Operating Income) with the amount of investment or assets used to generate these operating profits (Net Operating Assets).

According to (Prihadi, 2012, p. 166-167) states that Return On Assets (ROA) is a ratio to find out how far the assets used can generate profits. Thus, this ratio is to determine the overall results before interest expense on debt compared to total assets. According to (Kasmir, 2012 p. 201) the purpose of using Return On Assets for companies and outside parties, namely:

1 To measure or calculate the profit earned by the company in a certain period

2 To assess the company's profit position from the previous year to the current year

3 To assess the progress of profit over time

4 To assess the amount of net profit after tax with own capital

5 To measure all company funds used both own capital

Measurement of Return On Asset (ROA) According to (Harahap, Sofyan, 2011 p. 304 ) is measured by a ratio using the following equation:

Return On Asset $(R O A)=$ Net Income After Tax

Working Capital is an important factor in a company, each company is required to have working capital for the operation of a company which is used to buy raw materials, pay employee wages, pay debts and other payments that must be made by the company (Julita, 2015). This working capital aims to meet the profitability needs of the company. If the financial ratios meet the requirements, the company can get additional funds from the creditor.

According to (Kasmir, 2016 pp. 252-253) the importance of working capital for companies, especially for company health, is as follows:

1 The activities of a financial manager are mostly spent in the company's operational activities from time to time. This is working capital management

2 Investments in current assets are fast and change frequently and tend to be volatile. Meanwhile, current assets are the working capital of the company, which means that the decline will affect working capital. Therefore, it is necessary to get serious attention from the financial manager.

3 In practice, it is often the case that half of the total assets are part of the current assets which is the working capital of the company.

4 For relatively small companies, the function of working capital is very important. Small companies are relatively limited to entering large and long-term capital 


\section{International Journal of Business Economics (IJBE)}

Vol, 2 Issue 2, pp 143-154, March - August 2021

http://jurnal.umsu.ac.id/index.php/ijbe

eISSN 2686-472X

markets. Company funding relies more on short-term debt. Like trade payables, one year bank debt which of course can affect working capital.

5 There is a very close relationship between sales growth and working capital requirements.

Working Capital used to carry out company operations. Working Capital can also be interpreted as an investment that is invested in current assets or short-term assets such as cash, marketable securities, receivables, inventories and other current assets.

According to (Kasmir, 2010 p. 211) the formula used to find working capital is:

Working Capital $=$ Current Assets - Current Debt

Fixed assets turnover is the position of fixed assets and the estimated turnover time of fixed assets can be assessed by calculating the turnover rate of fixed assets by dividing sales by total net fixed assets. It can be concluded that fixed assets turnover is determined by two main factors, namely sales and total net fixed assets. What is meant by total net assets is total fixed assets after deducting the depreciation of fixed assets. "Assets are money and other securities that are very liquid which can be cashed at any time and other valuable documents that are very fluent meet the requirements." (Please, Sofyan, 2010 p. 310) The following is the objective of asset turnover.

According to (Syamsuddin, 2011 p. 89) the basic strategy carried out by the company in managing its assets is as follows:

1 Pay trade payables as late as possible as long as you don't reduce the trust of the supplier to the company, but take advantage of any cash discounts that put the company first

2 Manage inventory turnover as quickly as possible but avoid the risk of inventory habits that can cause losses to the company in the future.

3 Collect receivables as quickly as possible but do not cause the possibility of a decrease in sales volume in the future due to strict policies on credit sales and collection of accounts receivable.

According to (Sutrisno, 2010 p. 267) asset turnover is measured using the formula:

Asset Turnover $=\quad$ Sales

$$
\text { Total Asset }
$$

Sales Growth reflects the success of the company's operations in the past period and can be used as a prediction for future Sales Growth. Sales growth is a change in the company's total sales. (Sadag, 2015). A different company in an industry that has a high growth rate must provide sufficient capital to finance the company. "Companies that grow rapidly tend to use debt more than companies that grow slowly" (F, Brighan \& Houston, Joel, 2010).

The goals of sales growth are:

1 Reach a certain sales volume

2 With sales activities are expected to get a certain profit

3 With sales activities, it is hoped that it can support the company's growth

According to (Sadag, 2015), sales growth reflects the success of the company's operations in the past period and can be used as a prediction of future growth. Sales growth is calculated as follows: 
Vol, 2 Issue 2, pp 143-154, March - August 2021

http://jurnal.umsu.ac.id/index.php/ijbe

eISSN 2686-472X

Sales Growth $=\frac{\text { Sales }- \text { Sales } \mathrm{t}-1}{\text { Sales } \mathrm{t}-1}$

\section{RESULTS AND DISCUSSION \\ Normality test}

The normality test is used to test whether the regression model between the independent variable and the dependent variable has a normal distribution, this can be seen by testing the P-plot graph, the VIF value and the scatterplot.

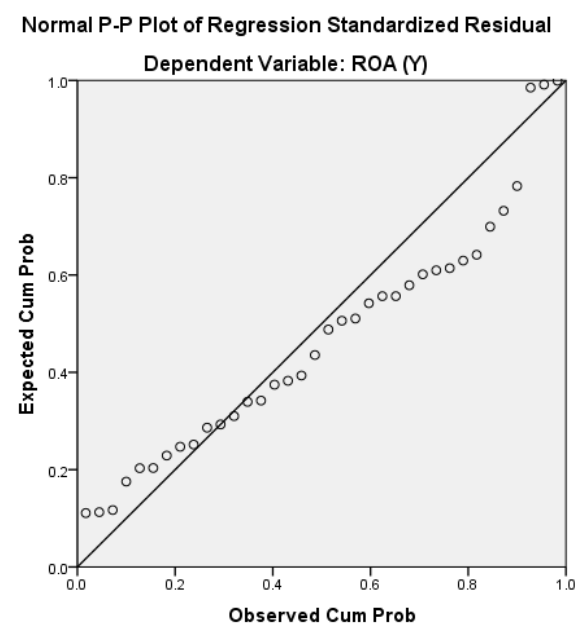

Figure 1. Data Normality P-Plot Results

Based on the picture above, it can be seen that the results of the data normality test show that the distribution of data points tends to approach the diagonal line or the histogram graph shows a normal distribution pattern, so the regression model fulfills the normality assumption, this means that the regression method is normally distributed and feasible for analysis.

The multicollinearity test aims to test whether there is a correlation between the independent variables in the regression model. If multicollinearity occurs in the regression model, the regression coefficient cannot be estimated and the standard error value becomes infinite.

Table 1. Variance Inflation Factor (VIF) value

\begin{tabular}{|c|c|c|c|c|c|c|c|}
\hline \multicolumn{8}{|c|}{ Coefficients $^{\mathrm{a}}$} \\
\hline \multirow[b]{2}{*}{ Model } & \multicolumn{2}{|c|}{$\begin{array}{c}\text { Unstandardized } \\
\text { Coefficients } \\
\end{array}$} & \multirow{2}{*}{$\begin{array}{c}\text { Standardized } \\
\text { Coefficients } \\
\text { Beta }\end{array}$} & \multirow[b]{2}{*}{$\mathrm{t}$} & \multirow[b]{2}{*}{ Sig. } & \multicolumn{2}{|c|}{ Collinearity Statistics } \\
\hline & $\mathrm{B}$ & $\begin{array}{c}\text { Std. } \\
\text { Error }\end{array}$ & & & & Tolerance & VIF \\
\hline $\begin{array}{ll}1 & \text { (Constant })\end{array}$ & 0.190 & 0.060 & & 3.152 & 0.004 & & \\
\hline Working Capital (X1) & -0.006 & 0.006 & -0.184 & -1.059 & 0.297 & 0.962 & 1.039 \\
\hline Assets Turnover (X2) & -0.021 & 0.037 & -0.105 & -0.579 & 0.567 & 0.871 & 1.148 \\
\hline Sales Growth (X3) & -0.267 & 0.198 & -0.246 & -1.352 & 0.186 & 0.876 & 1.141 \\
\hline
\end{tabular}




\section{International Journal of Business Economics (IJBE)}

Vol, 2 Issue 2, pp 143-154, March - August 2021

http://jurnal.umsu.ac.id/index.php/ijbe

eISSN 2686-472X

From the data in the table above, it can be seen that the Variance Inflation Factor (VIF) value for each independent variable does not have a value greater than 10. Likewise, the Tolerance value for each variable has a tolerance value greater than 0.1 , so it can be concluded that There is no multicollinearity symptom between the independent variables as indicated by the tolerance value of each independent variable greater than 0.1 and the VIF value less than 10, so it can be concluded that further analysis can be carried out using multiple regression models.

The heteroscedasticity test aims to test whether in the regression model there is an inequality of variance from the residuals of one observation to another. A good regression model does not occur heteroscedasticity. How to detect the presence or absence of heteroscedasticity is to look at the plot graph between the predicted values of the dependent variable. The basis of analysis to determine the presence or absence of heteroscedasticity is:

If there is a certain pattern, such as the dots forming a certain regular pattern (wavy, widening then narrowing), it indicates that heteroscedasticity has occurred.

If there is no clear pattern, and the dots spread above and below the 0 on the $\mathrm{Y}$ axis, then there is no heteros

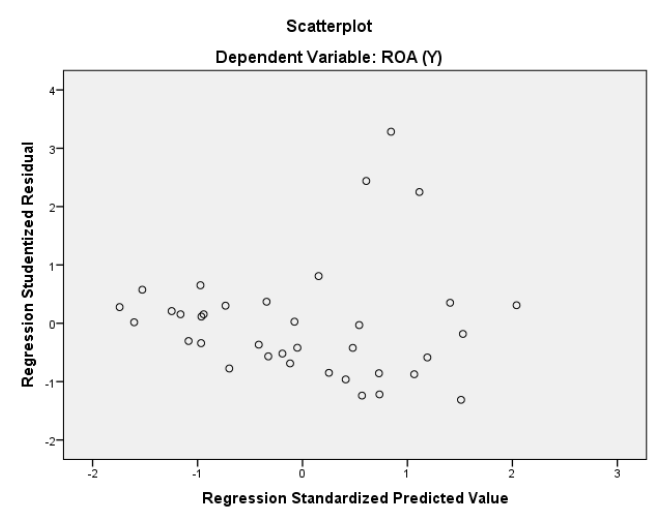

Figure 2. Scatterplot of Heteroscedasticity Test

In the picture above shows the points spread randomly, do not form a clear / regular pattern, and are scattered both at and below the number 0 on the $\mathrm{Y}$ axis. Thus, it can be concluded that there is no heteroscedasticity in the regression model.

This test aims to test whether in a linear regression model there is a correlation between the accounting error in a period and the error in the $\mathrm{t}-1$ period (before). If there is a correlation, it is called an autocorrelation problem. One way to identify it is by looking at the Durbin Watson value (DW).

Table 2. Durbin Watson value (DW).

\begin{tabular}{llllll}
\hline \multicolumn{7}{c}{ Model Summary $^{\mathrm{b}}$} \\
\hline Model & $\mathrm{R}$ & $\mathrm{R}$ Square & Adjusted R Square Estimate & \multicolumn{2}{c}{ Std. Error of the } \\
\hline 1 & $0.273^{\mathrm{a}}$ & 0.075 & -0.012 & 0,117378 & 0.936 \\
\hline
\end{tabular}

a. Predictors: (Constant), Working Capital (X1), Assets Turnover (X2), sales growth (X3)

b. Dependent Variable: ROA (Y)

From the results above, it is known that the Durbin Watson value obtained is 0.936 which is included in the third criterion. Furthermore, this value will be compared with the 


\section{International Journal of Business Economics (IJBE)}

Vol, 2 Issue 2, pp 143-154, March - August 2021

http://jurnal.umsu.ac.id/index.php/ijbe

eISSN 2686-472X

Durbin Watson table value at $5 \%$ significance with the formula $(\mathrm{k} ; \mathrm{N})$. The number of independent variables is 3 or " $\mathrm{k} "=3$, while the number of samples or "N" $=36$, then $(\mathrm{k} ; \mathrm{N})$ $=(3 ; 36)$. This figure then we look at the distribution of the durbin watson table value, it is found that the $\mathrm{dL}$ value is 1.2953 and the $\mathrm{dU}$ is 1.6539 .

The Durbin-Watson (D-W) value of 0.936 is smaller than the dL which is 1.2953 So as the basis for making decisions in the Durbin-Watson test above, it can be concluded that there is autocorrelation. Multiple linear regression analysis aims to see how much the regression coefficient affects the dependent variable.

Table 3. Multiple linear regression

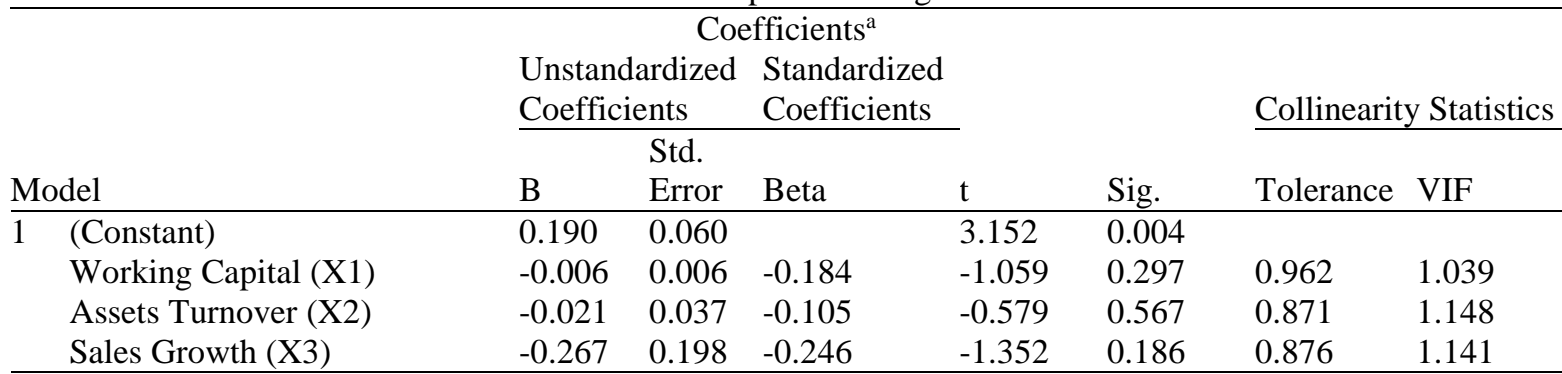

a. Dependent Variable: ROA (Y)

\section{Multiple Linear Regression Test Results}

From the table above, it is known the values as follows:

$\begin{array}{ll}\text { Constant } & =0.190 \\ \text { Working Capital } & =-0.006 \\ \text { Asset Turnover } & =-0.021 \\ \text { Sales Growth } & =-0.267\end{array}$

These results are entered into the multiple linear regression equation so that the following equation is known $\mathrm{Y}=0.190-0.006 \mathrm{X} 1-0.021 \mathrm{X} 2-0.267 \mathrm{X} 3$, with interpretation a constant of 0.190 with a positive direction indicating that if the independent variable is considered constant, profit growth has increased by 0.190 , of 0.006 with a negative relationship direction, indicating that every $1 \%$ increase in Working Capital will be followed by a decrease in Return On Assets of 0.006 or $0.6 \%$, assuming other independent variables are considered constant, B2 of -0.021 with the direction of the negative relationship, indicating that every $1 \%$ increase in Asset Turnover will be followed by a decrease in Return On Assets of 0.021 or $2.1 \%$, assuming other independent variables are considered constant, B3 is -0.267 with the direction of the negative relationship, indicating that every $1 \%$ increase in Sales Growth will be followed by a decrease in Return On Assets of 0.267 or $26.7 \%$, assuming other independent variables are considered constant.

\section{Hypothesis test \\ T test (Partially)}

The $t$ test is used in this study to determine the ability of each independent variable to influence the dependent variable. Another reason for the t test is to test whether the independent variable $(\mathrm{X})$ individually has a significant relationship or not to the dependent variable (Y).

The formula used in this research is as follows

$$
t=\frac{\sqrt[r]{n-2}}{\sqrt{1-r^{2}}}
$$


$\mathrm{t}=\mathrm{t}$ count value

$\mathrm{r}=$ correlation coefesien

$\mathrm{n}=$ number of rank pairs

Test form:

$\mathrm{H} 0$ : rs $=0$, meaning there is no significant relationship between the free variable $(\mathrm{X})$ and the bound variable $(\mathrm{Y})$.

$\mathrm{H} 0: \mathrm{rs} \neq 0$, meaning there is a significant relationship between a free variable $(\mathrm{X})$ and a bound variable (Y).

Decision-making criteria:

$\mathrm{H} 0$ is accepted if : $-\mathrm{t}_{\text {tabel }} \leq \mathrm{t}_{\text {hitung }} \leq \mathrm{t}_{\text {tabel, }}$, at $\alpha=5 \%$, $\mathrm{df}=\mathrm{n}-\mathrm{k}-1$

$\mathrm{H} 0$ is rejected if : $t_{\text {hitung }}>t_{\text {tabel }}$ or $-t_{\text {hitung }}<-t_{\text {tabel }}$

Table 4. T test (Partially)

\begin{tabular}{|c|c|c|c|c|c|c|c|}
\hline \multicolumn{8}{|c|}{ Coefficients $^{\mathrm{a}}$} \\
\hline & \multicolumn{2}{|c|}{$\begin{array}{l}\text { Unstandardized } \\
\text { Coefficients }\end{array}$} & \multicolumn{2}{|c|}{$\begin{array}{l}\text { Standardized } \\
\text { Coefficients }\end{array}$} & \multirow[b]{2}{*}{ Sig. } & \multicolumn{2}{|c|}{ Collinearity Statistics } \\
\hline Model & B & $\begin{array}{l}\text { Std. } \\
\text { Error }\end{array}$ & Beta & $\mathrm{t}$ & & Tolerance & VIF \\
\hline $\begin{array}{ll}1 & \text { (Constant) }\end{array}$ & 0.190 & 0.060 & & 3.152 & 0.004 & & \\
\hline Working Capital (X1) & -0.006 & 0.006 & -0.184 & -1.059 & 0.297 & 0.962 & 1.039 \\
\hline Assets Turnover (X2) & -0.021 & 0.037 & -0.105 & -0.579 & 0.567 & 0.871 & 1.148 \\
\hline Sales Growth (X3) & -0.267 & 0.198 & -0.246 & -1.352 & 0.186 & 0.876 & 1.141 \\
\hline
\end{tabular}

Partial Test Result (t-test), for t-test criteria performed at $a$ level $=5 \%$ in one direction (0.05). The value $t$ for $n=36-3-1=32$ is 2,037

\section{F test (Simultaneously)}

Test $\mathrm{F}$ is conducted to determine the overall ability of the influence between free variables on bound variables to be able to explain diversity, as well as to find out if all variables have simultaneous relationships. This $\mathrm{F}$ test is also performed to find out if all variables are bound or have a regression coefficient equal to 0 . Partial Test Result (t-test) For $\mathrm{t}$-test criteria performed at $\mathrm{o}$ level $=5 \%$ in one direction $(0.05)$. The value $\mathrm{t}$ for $\mathrm{n}=36$ $3-1=32$ is 2,037 b. Simultaneous Test (Test F) Test F is conducted to determine the overall ability of the influence between free variables on bound variables to be able to explain diversity, as well as to find out if all variables have simultaneous relationships. This $\mathrm{F}$ test is also performed to find out if all variables are bound or have a regression coefficient equal to 0 .

Table 5. F test (Simultaneously)

\begin{tabular}{lllllll}
\hline \multicolumn{7}{c}{ ANOVA $^{\mathrm{a}}$} \\
\hline Model & Sum of Squares & df & Mean Square & F & Sig. \\
\hline 1 & Regression & 0.036 & 3 & 0.012 & 0.860 & $0.472^{\mathrm{b}}$ \\
& Residual & 0.441 & 32 & 0.014 & & \\
& Total & 0.476 & 35 & & & \\
\hline
\end{tabular}

a. Dependent Variable: ROA (Y)

b. Predictors: (Constant), Working Capital (X1), Assets Turnover (X2), Sales Growth (X3) 


\section{International Journal of Business Economics (IJBE)}

Vol, 2 Issue 2, pp 143-154, March - August 2021

http://jurnal.umsu.ac.id/index.php/ijbe

eISSN 2686-472X

For test criteria F: Is performed at the level of $a=5 \%$ with the value $\mathrm{f}$, for ftabel $=\mathrm{n}-\mathrm{k}-1=$ $36-3-1=32$ is 2.51

\section{The Coefficient of Determination (R2)}

This coefficient of determination is used to determine how much influence free variables have on their bound variables. The determination efficiency value is determined by the $\mathrm{R}$ square value.

Table 6. Coefficient of Determination (R2)

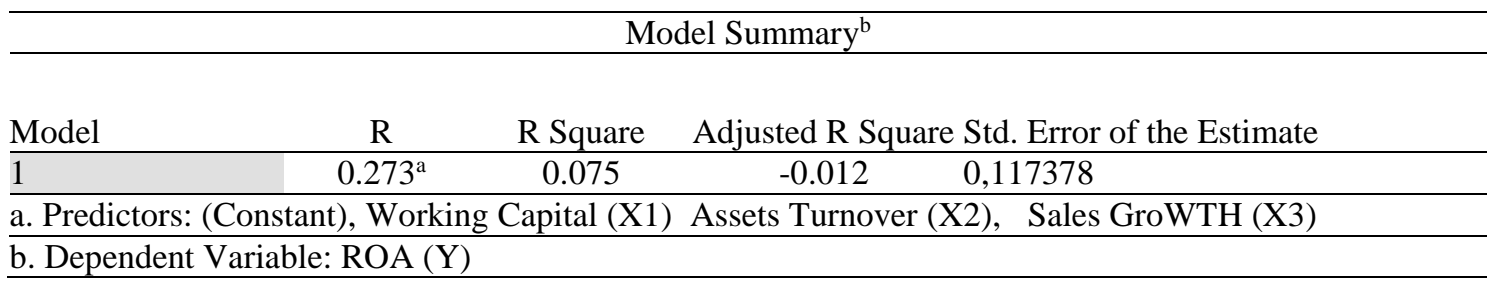

Based on the above can show that the value of R-Square (R2) of 0.075 or 7.5 which means that the percentage of independent variable influence (Debt to Equity Ratio, Net Profit Margin and Return On Equity) on dependent variables (Share Price) is 7.5\%.

\section{DISCUSSION}

\section{The Effect of Working Capital on Return On Asset (ROA)}

Test $\mathrm{t}$ is used to determine whether Working Capital has an individual (partial) effect on Return On Asset. (ROA). Partial hypothetical test results show that the thitung value for the Working Capital variable. is -1.059 and thet tabel with a known $a=5 \%$ is 2,037 . Thus $t_{\text {hitung }}$ is smaller than $t_{\text {tabel }}(-1,059<2,037)$ and a significant value of 0.297 greater than 0.05 , meaning $\mathrm{H}_{\mathrm{o}}$ is accepted and $\mathrm{H}_{\mathrm{a}}$ is rejected. Based on these results shows that partially no influence and insignificant Working Capital on Return On Asset.on food and beverage companies listed on the Indonesia Stock Exchange .

Based on research obtained (Dahrani \&Maslinda, 2015) Working Capital has no significant effect on Return On Asset (ROA) in increasing the company's profit. The results of the study (Sri, 2015) conducted research with working capital variables against Return On Asset (ROA). The results show that partially all free variables have a significant effect on Return On Asset (ROA). Based on research (Burhanudin, 2017) conducted research by testing the variable free Working Capital (Work Capital Turnover) against Return On Asset (ROA). Where the results of the study showed that persially working capital variables have a significant effect on Return On Asset (ROA). Therefore, the results of this study stated that there is no significant influence on working capital listed on the Indonesia Stock Exchange for the period 2017-2019.

\section{The effect of Asset Turnover on Return On Asset}

Uji $t$ is used to determine whether the Asset Turnover has an individual (partial) effect on Return On Asset (ROA). Partial hypothetical test results showed that the thitung value for the Asset Turnover variable was -0.579 and the value with $\alpha=5 \%$ was known at 2,037 . Thus $t_{\text {hitung }}$ is smaller than $t_{\text {tabel }}(-0.579<2.037)$ and a significant value of 0.567 greater than 0.05 , meaning $\mathrm{H}_{\mathrm{o}}$ is accepted and $\mathrm{H}_{\mathrm{a}}$ is rejected. Based on these results 


\section{International Journal of Business Economics (IJBE)}

Vol, 2 Issue 2, pp 143-154, March - August 2021

http://jurnal.umsu.ac.id/index.php/ijbe

eISSN 2686-472X

showed that partially no influence and insignificant Asset Turnover on Return On Asset.on food and beverage companies listed on the Indonesia Stock Exchange The results of research conducted (Linzzy Pratami Putri, 2015) stated Total Asset Turnover (TATO) has a significant positive effect and does not signifikan to Return On Asset (ROA)

From the results of the study (Sugiyono, 2010) of the variable turnover of assets or free variables that are variables that affect or be the cause of the change or arise variables tied Return On Asset (ROA). Therefore, the results of this study stated that there is no significant influence on the turnover of assets listed on the Indonesia Stock Exchange for the period 2017-2019

\section{The effect of Sales Growth on Return On Asset}

Uji $t$ is used to determine whether Sales Growth has an individual (partial) effect on Return On Asset (ROA). Partial hypothetical test results showed that the thitung value for the Sales Growth variable was $-0.1,352$ and the value with a known $\alpha=5 \%$ was 2,037. With thus thitung is smaller than $\mathrm{t}_{\text {tabel }}(-1,352<2,037)$ and a significant value of 0.186 greater than 0.05 , meaning $\mathrm{H}_{\mathrm{o}}$ is accepted and $\mathrm{H}_{\mathrm{a}}$ is rejected.

Based on these results showed that partially no influence and insignificant Sales Growth on Return On Asset.in food and beverage companies listed on the Indonesia Stock Exchange This is in line with the opinion expressed by (Hastuti, 2010) that sales growth does not have a significant impact on Profitability (ROA). According to (Habibah, 2019) concluded that sales growt showed partially no significant effect on Return On Asset (ROA). Research conducted by (Kaptiana \&Asandimitra, 2013) concluded that sales growth is negative to Profitability (ROA).

Based on the results of research conducted by research and theory, opinions and previous research presented above on the influence of Sales Growth on Return On Asset, the authors can conclude that there is no significant effect on food and beverage companies listed on the Indoensia Stock Exchange for the period 2017-2019

\section{The influence of Working Capital, Asset Turnover and Sales Growth on Return} On Assets

Based on F test that tests simultaneously whether the three variables are free to variables namely Working Capital, Asset Turnover and Sales Growth have a significant influence on Return On Asset (ROA), then obtained f $f_{\text {hitung }}$ of 0.860 with a significant level of 0.472 while $\mathrm{f}_{\text {tabel }} 2.51$ with a significant 0.05 . Thus $\mathrm{HO}$ was accepted and $\mathrm{H}_{\mathrm{a}}$ rejected. So it can be concluded that Working Capital, Asset Turnover and Sales Growth together have no influence on Return On Asset (ROA) because $\mathrm{f}_{\text {hitung }}<\mathrm{ft}_{\text {abel }}(0.860<2.51)$ and its significant value of $0.472<0.05$.

According to (Rachmawati, 2018) the turnover of assets against Return On Asset (ROA) in general turnover of assets there is a significant effect on Return On Asset (ROA). (Kaptiana \&Asandimitra, 2013) concluded that sales growth had a significant effect on Profotability (ROA). Based on the results of research conducted by the author and the theory of opinion, as well as previous research that has been stated above on the influence of Working Capital, Asset Turnover and Sales Growth on Return On Asset (ROA) it does not have a significant influence on Return On Asset (ROA) in food and beverage companies listed on the Indoensia Stock Exchange for the period 2017-2019.

\section{CONCLUSION}




\section{International Journal of Business Economics (IJBE)}

Vol, 2 Issue 2, pp 143-154, March - August 2021

http://jurnal.umsu.ac.id/index.php/ijbe

eISSN 2686-472X

Based on the results of research and discussion that has been previously stated, it can be concluded from the research on the influence of Working Capital Asset Turnover and Sales Growth on Return On Asset (ROA) on Food and beverages listed on the Indonesia Stock Exchange (IDX)2017-2019 with a sample of 12 companies are as follows: Partial research results have no significant influence of Working Capital, Asset Turnover and Sales Growth on Return On Assets in Food and Beverage Sector companies listed on the Indonesia Stock Exchange period 2017-2019. The advice that can be given this research is as follows: The company is expected to be able to control the level of capital of the company well, because if the company's model is too low it will adversely affect the company's capital and will result in pride.

The company is expected to be able to control the level of sales within the company. But the company must also control the cash, its assets in order to generate profit will also be maximal. The Company is expected to be able to control its short-term debt as seen from the turnover of its assets that serves to pay off its short-term debt. If the company is unable to pay off its short-term debt then the company increases sales and increases profit and minimizes its operating costs. If the company still wants the smooth running of its business activities are not disrupted so as to increase the profit suggested the total amount of assets financed by the owner of the existing company can be empowered for the company's activities to increase profit or profit.

\section{REFERENCES}

Alpi, M, F., \& Gunawan, A. (2018). Pengaruh Current Ratio dan Total Asset Turnover terhadap Return On Asset pada Perusahaan Plastik dan Kemasaan. Jurnal Riset Akuntasi Aksioma, 17(2), 1-35.

Alpi, M. F., \& Gunawan, A. (2018). Pengaruh Current Ratio Dan Total Assets Turnover Terhadap Return On Assets Pada Perusahaan Plastik Dan Kemasaan. Jurnal Riset Akuntasi Aksioma, 17(2), 1-36.

Ambarwati, N. S., Yuniarta, G. A., \& Sinarwati, N. K. (2015). Pengaruh Modal Kerja, Likuiditas, Aktivitas dan Ukuran Perusahaan terhadap Profitabilitas pada Perusahaan Manufaktur yang terdaftar diBursa Efek Indonesia. E-Journal S1 Ak Universitas Pendidikan Genesha, 3(1), 2-4.

Burhanudin. (2017). Penagruh Struktur Modal Perputaran Aktiva TerhadapProfitbilitas Pada Perusahaan Otomatif Yang Terdaftar Di Bursa Efek Indonesia. Jurnal Akuntasi, 4(1), 43-48.

F, Brighan, E., \& Houston, Joel, F. (2010). Dasar-Dasar Manajemen Keuangan. Selemba Empat.

Gunawan, A. (2018). Pengaruh Current Ratio Dan Total Asset Turnover Terhadap Return On Asset Pada Perusahaan Plastik Dan Kemasaan. Jurnal Riset Akuntasi Aksioma, 17(2), 5-8.

Habibah, S. (2019). Pengaruh Penjualan Dan Utang Terhadap Profitabilitas Pada PT Perkebunan Nusantara IV Medan Periode 2008-2017. Jurnal Akuntasi Dan Keuangan, 4(2), 32-35.

Harahap, Sofyan Syafri. (2011). Analisis Kritis Atas Laporan Keuangan. Jakarta Charisma Putra Utama Offset.

Hastuti, N. (2010). Analisis pengaruh periode perputaran persedian. periode perputaran hutang dagang, rasio lancar, leverage, pertumbuhan penjualan dan ukuran perusahaan terhadap profitabilitas perusahaan (studi pada: perusahan manufaktur yang terdaftar di BEI pada tahun 200. universitas diponegoro. 
Vol, 2 Issue 2, pp 143-154, March - August 2021

http://jurnal.umsu.ac.id/index.php/ijbe

eISSN 2686-472X

Hotimah, C., \& Joni, S. (2014). Pengaruh Struktur Modal, Modal Kerja Dan Pertumbuhan Penjualan Terhadap Profitabilitas. Jurnal Ilmu Manajemen, 2(2), 45-47.

Julita. (2012). Pengaruh Debt To Equity Ratio Dan Long Term Debt To Equity Ratio Terhadap Profitabilitas Perusahaan.(Studi Khasus Pada Perusahaan Telekomunikasi Yang Terdaftar Di Bursa Efek Indonesia). Jurnal Dosen UniversitasMuhammadiyah Sumatera Utara, 7(2), 1-25.

Julita. (2015). Pengaruh Perputaran Modal Kerja Dan Perputaran Kas Terhadap Likuiditas Pada Perusahaan Pertambangan Yang Terdaftar Di Bursa Efek Indoensia. Jurnal Dosen UniversitasMuhammadiyah Sumatera Utara, 9(02), 1-9.

Kaptiana, D. I., \& Asandimitra, N. (2013). Pengaruh Struktur Modal Resiko Bisnis, Dan Pertumbuhan Penjualan Terhadap ROE Perusahaam Manufaktur. Jurnal Bisnis Dan Manajemen, 6(2), 122-129.

Kasmir. (2010). Pengantar Manajemen Keuangan. Kencana Prenada Media Group.

Kasmir. (2011). Analisis Laporan Keuangan. PT Raja Grafindo Persada.

Kasmir. (2016). Analisis Laporan Keuangan. Raja GrafindoPersada.

Meidiyustiani, R. (2016). Pengaruh Modal Kerja Ukuran Perusahaan PertumbuhanPenjualan Dan Likuiditas Terhadap Profitabilitas Pada Perusahaan

Manufaktur Industri Barang Konsumen Yang Terdaftar di Bursa Efek Indonesia (BEI). Jurnal Akuntasi Dan Keuangan, 5(2), 47.

Putri, Linzzy Pratami. (2015). Pengaruh profitabilitas terhadap harga saham. Jurnal

Ilmiah Manajemen Dan Bisnis, 16(02), 52.

Rachmawati, S. (2018). Analisis Perputaran Utang Dan Perputaran Aktiva Tetap Terhadap Profitabilitas Pada PT. Gudang Garam Tbk. Jurnsl Ekonomi Dan Ekonomi Syariah, 1(2), 2-12.

Sadag, N. J. (2015). Pertumbuhan Penjualan, Ukuran Perusahaan, Return On Asset Struktur Modal terhadap nilai Perusahaan yang tercatat di Indeks. Jurnal EMBA, 3(3), 214-225.

Swastha, B. (2010). Manajemen Penjualan. BPFE.

Syamsuddin, L. (2011). Analisis Protofolio. Erlangga.Toto, P. (2011). Analisis Laporan Keuangan. Pt Gramedia Pustaka. 